\title{
Mitigating Toxic Effects of Nigerian Bonnylight Crude Oil on Sperm Motility and Morphology of Wistar Rats with Ethanol Leaves Extract of Ageratum Conyzoides Supplementation
}

\author{
Sunday Otu Ita*, Effiong FE, Udokang NE, Uzoma, JC, Etim EE and Francis UE \\ Department of Physiology, Faculty of Basic Medical Sciences, College of Health Sciences, University of Uyo, Uyo, Akwa Ibom \\ State, Nigeria
}

*Corresponding author: Sunday Otu Ita, Department of Physiology, Faculty of Basic Medical Sciences, College of Health Sciences, University of Uyo, Uyo, Akwa Ibom State, Nigeria

ARTICLE INFO

Received: 㓞 July 10, 2020

Published: July 24, 2020

Citation: Sunday Otu Ita, Effiong FE, Udokang NE, Uzoma, JC, et al., Mitigating Toxic Effects of Nigerian Bonnylight Crude Oil on Sperm Motility and Morphology of Wistar Rats with Ethanol Leaves Extract of Ageratum Conyzoides Supplementation. Biomed J Sci \& Tech Res 29(1)-2020. BJSTR. MS.ID.004751.

Abbreviations: ASAS: Antisperm Antibodies; BCF: Beating Cilia Frequency; LIN: Linearity; SFR: Straight forward line; PR: Progressivity; NBLCO: Nigerian Bonny Light Crude Oil; IM: Immotility; VAP: Velocity of Active Path; VCL: Velocity of Curve Line; TAR: Total Abnormality Rate; CASS: Computer Assisted Semen Analysis; NR: Normality Rate; NSC: Normal Sperm Cells; HAR: Head Abnormality Rate; BAR: Body Abnormality Rate; TAR: Total Abnormality Rate; TMS: Total Motile Sperm; PMS: Percentage Of Motile Sperm; PR: Progressivity; TSCC: Total Sperm Cell Concentration

\section{ABSTRACT}

The capacity of Ageratum Conyzoides extract to mitigate toxicity of Nigerian Bonnlight crude oil on sperm motility and morphology of Wistar rats was investigated. Twenty male Wistar rats (120-145g body weight) were divided into four groups of five rats each. Group I rats gavaged $3 \mathrm{ml} / \mathrm{kg}$ of normal saline served as control; group II gavaged $748.33 \mathrm{mg} / \mathrm{kg}$ body weight of the extract of Ageratum Conyzoides, group III gavaged $3 \mathrm{ml} / \mathrm{kg}$ body weight of NBLCO; and group IV animals administered the aforementioned doses of the extract and NBLCO for 31 days. Ethanol leaf extract of Ageratum Conyzoides significantly increase total sperm cell detected (TSCD) and total sperm cell concentration (TSCC) while the administration of NBLCO significantly reduced these parameters, $(\mathrm{p}<0.05)$. Similarly, co-administration of Ageratum Conyzoides with NBLCO significantly increased TSCD and TSCC with respect to the NBLCO group III, $(\mathrm{p}<0.05)$. Ageratum Conyzoides significantly maintained normal sperm morphology while NBLCO significantly altered sperm morphology negatively, $(\mathrm{p}<0.05)$. The co-administration of A. Conyzoides with NBLCO significantly restored normal sperm morphology, $(\mathrm{p}<0.05)$. While Ageratum conyzoides significantly increase motility indices and reduce the percentages of immotile sperm and non-progressivity significantly, NBLCO significantly elevated percentages of immotile sperm and nonprogressivity, $(\mathrm{p}<0.05)$. The results of co-administration of Ageratum conyzoides with NBLCO significantly increase motility indices but reducing the percentages of immotile sperm and non-progressivity sperm, $(p<0.05)$. It is concluded that NBLCO administration could induce infertility by interference with sperm concentration, morphology and motility, which ethanol leaf extracts of Ageratum conyzoides has been confirmed to show some therapeutic potentials of recovering.

Keywords: Ageratum conyzoides; Crude Oil; Morphology; Motility; Sperm; Wistar Rats

\section{Introduction}

Crude petroleum and aromatic hydrocarbons are among environmental pollutants with estrogenic tendency reported to have directly and indirectly impacted negatively on reproductive health with a decline in fertility of human and wildlife [1-4]. This has been illustrated to reduce sperm count, motility and distorted morphology in experimental rats exposed to Bonnylight crude oil [5-7]. Infertility characterized with low semen quality, like many other health conditions has multifactorial etiologies, ranging from genetic to lifestyle to environmental exposure to pollutants. Sperm 
motility and morphology are important parameters for sperm viability and play critical role in determination of semen quality. Distortion of the aforementioned parameters lead to deficiencies in the semen quality and can impact negatively on male fertility due to high sensitivity to many of the harmful chemical and physical agents generated into the environment $[8,9]$. The ability of a sperm cell to freely move to interact with an ovum is crucial in determining the capacity of such sperm to fertilize an ovum.

It is also important to focus attention on how interference with normal spermatozoa movement can influence their viability. Therefore, proper evaluation of sperm concentration, motility and morphology are veritable properties required for effective and efficient sperm functions. Normal sperm motility and shape are essential for easy passage through the highly viscous cervix wall, uterus, and ampullae of the oviducts of the female organism to reach the ovum. Distortion in sperm's apparati (contractile proteins of the tail) for movement motility and morphology can prevent the sperm's contact with an ovum to prevent fertilization $[10,11]$ Exposure to toxic chemicals in petroleum can damage the sperm by compromising the cellular membrane integrity and contractile proteins through lipid peroxidation and inflammation processes. The excessive production of free radicals during these processes can be detrimental to sperm by destroying the contractile proteins and lipid components of the sperm membrane; the sperm plasma membrane contains a high amount of unsaturated fatty acids making it particularly susceptible to peroxidative damage $[12,13]$.

This destroys the structure of membrane lipid matrix to account for defective membrane integrity [14], and poor motile capacity due to the destructions of contractile protein elements in sperm tail. The ease with which spermatozoa pass through highly viscous cervical mucus is highly dependent on their rapid progressive motility $[15,16]$, which in turn is dependent on the integrity of the contractile components of the sperm membrane, particularly the tail. Normal semen that is viable must as a matter of fact contain at least $50 \%$ of sperm that are progressively motile. And if for any reason, the semen contains up to $50 \%$ or more of immotile sperms then the viability of such semen is in doubt. This may suggest infertility as persistent poor motility is reported to be a good predictor of failure of sperm cell to fertilize an ovum [17]. Furthermore, oxidative stress and inflammation are closely related processes in the seminal fluid that can evoke immune responses with the attended consequences of formation of Antisperm Antibodies (ASAs).

ASAs can be detrimental to sperm's health where they exhibit cytotoxic tendency on the spermatozoa as well as the immobilization of sperm cells and even sperm death. With the production of ASAs as a result of inflammation coagulability tendency is enhanced to increase agglutination of moving sperm in semen, this agglutinated semen in turn immobilize the sperm, and impede free passage of sperm through the mucus-rich cervical wall, uterus to the fallopian tube to interact with the ovum [18]. Mitigation of these processes by the promotion of the antioxidant systems is essential to improve sperm motility. In furtherance to this, focus on natural reservoir of bioactive agents with various identified phytochemicals like antioxidants is apt. Plants have long been identified as natural reservoir of bioactive agents with various identified phytochemicals like antioxidants [19-25]. One of such plants with bioactive constituents is Ageratum conyzoides.

Ageratum conyzoides (billy goat-weed, chickweed, goat weed, white weed) is an annual herbaceous plant with long history of traditional medicinal uses in several countries of the world due its high bioactivity constituents. There is high variability in the secondary metabolites of Ageratum conyzoides which include terpenoids, sterols, flavonoids, chromenes, pyrrolizidine alkaloids, caumarin, pyrroline, lignin, essential oils and tannins. Since impede sperm motility is a consequence of oxidative stress and inflammation, this study was therefore designed to investigate the mitigating toxic effects of Nigerian Bonnylight crude oil on sperm motility and morphology of Wistar rats with ethanol leaves extract of Ageratum conyzoides supplementation.

\section{Materials and Methods}

The crude petroleum used in this study was obtained from the Nigerian National Petroleum Corporation (NNPC) Laboratory, Port Harcourt, Nigeria. The whole plant was obtained from the Botanical Farm of the Department of Pharmacognosy and Natural Medicine, University of Uyo, Nigeria. Specimen of the leaves was authenticated by an expert in the Department of Botany and Ecological Studies, University of Uyo. A voucher specimen (UUH 3517) was deposited at the Herbarium.

\section{Preparation of Leave Extract}

The leaves of A. conyzoides were rinsed with distilled water and dried under shade. The dried leaves were ground into powder with an electric blender. Four hundred grams of the blended leaves sample was macerated in $700 \mathrm{~mL} 70 \%$ ethanol agitated for 10 minutes with an electric blender and left overnight in a refrigerator at $4^{\circ} \mathrm{C}$. The mixture was filtered with a cheese cloth and the filtrate obtained concentrated under reduced pressure using a rotary evaporator (at $37^{\circ} \mathrm{C}$ ) to about $10 \%$ of its original volume. The concentrate was then allowed in a water bath at $37^{\circ} \mathrm{C}$ for complete evaporation to dryness yielding $40.64 \mathrm{~g}(10.16 \%)$ of the extract.

\section{Acute Toxicity Test}

Acute toxicity study $\left(\mathrm{LD}_{50}\right)$ was estimated using Lorke's method [26]. A total of 25 mice weighing between 15 and $22 \mathrm{~g}$ were divided into five groups with five mice per group. Mice in the five groups were respectively administered $3000 \mathrm{mg} / \mathrm{kg}, 3500 \mathrm{mg} / \mathrm{kg}$, 4000mg/ $\mathrm{kg}, 4500 \mathrm{mg} / \mathrm{kg}$ and $5000 \mathrm{mg} / \mathrm{kg}$ of body weight intraperitoneally. All experimental animals were observed for physical signs of toxicity such as gasping, palpitation, writhing, decreased respiratory rate, body limb and death after 24 hours. The median lethal dose of 
Ageratum conyzoides was calculated as geometrical means of the maximum (most tolerable) dose producing $0 \%$ mortality (a) and the minimum (least tolerable) dose producing $100 \%$ mortality (b) using the formula:

$$
\mathrm{LD}_{50}=\sqrt{\mathrm{ab} \mathrm{LD}} \mathrm{LD}_{50}=\sqrt{3500 \times 4000}=3741.66 \mathrm{mg} / \mathrm{kg} .
$$

The acute toxicity test for the NBLCO also involved 25 mice weighing between 15 and $22 \mathrm{~g}$ were divided into five groups with five mice per group. Mice in the five groups were administered intraperitoneally $10 \mathrm{~mL} / \mathrm{kg}, 15 \mathrm{~mL} / \mathrm{kg}, 20 \mathrm{~mL} / \mathrm{kg}, 25 \mathrm{~mL} / \mathrm{kg}$ and $30 \mathrm{~mL} / \mathrm{kg}$ of body weight respectively.

$$
\mathrm{LD}_{50}=\sqrt{10} \times 20=14.14 \mathrm{~mL} / \mathrm{kg} .
$$

\section{Experimental Animals}

Twenty male Wistar rats (120-145g body weight) were obtained from the Animal House of the Faculty of Basic Medical Sciences University of Uyo, Nigeria and were kept in a well-ventilated section of the Animal House. They were allowed access to feed (Chow: vital feeds, Grand Cereals Ltd, Jos) and water ad libitum. The animals were kept in separate experimental room and allowed to acclimatize for a period of one week before commencement of studies.

\section{Experimental Design and Treatment of Animals}

A total of twenty male Wistar rats (120-145g body weight) were randomly divided into four groups (I-IV) of five rats each. The rats in group I served as the control and were oral gavaged $3 \mathrm{~mL} / \mathrm{kg}$ of normal saline; group II were oral gavaged $748.33 \mathrm{mg} /$ $\mathrm{kg}$ body weight of the extract of Ageratum conyzoides, which was calculated as $20 \%$ of the $\mathrm{LD}_{50}(3741.66 \mathrm{mg} / \mathrm{kg})$. Group III was oral gavaged $3 \mathrm{~mL} / \mathrm{kg}$ body weight of NBLCO; this dose was calculated as $20 \%$ of the lethal dose of $14.14 \mathrm{~mL} / \mathrm{kg}$ and group IV animals were administered $748.33 \mathrm{mg} / \mathrm{kg}$ body weight of the extract of A. conyzoides and $3 \mathrm{~mL} / \mathrm{kg}$ body weight of NBLCO. In all cases, doses were applied daily for 31 days according to animal's most recent body weight. The experimental procedures involving the animals and their care were conducted in conformity with the approved guidelines by the Research and Ethical Committee of the Faculty of Basic Medical Sciences, University of Uyo, Nigeria.

\section{Collection of Blood Sample for Analysis}

After the thirty-one (31) days of administration, the rats were anaesthetized with sodium pentobarbital at $50 \mathrm{mg} / \mathrm{kg}$ intraperitoneally. And blood was collected by cardiac puncture with a $5 \mathrm{ml}$ sterile syringe and needle. The total volume of blood collected from the rat was averagely $4.5 \mathrm{ml}$, which was transferred into plain sample bottles. This was allowed to stand for 2 hours to clot after which the serum was separated by centrifugation (RM12 micro centrifuge, REMI, England) at 3000 rpm for 10 minutes at $25^{\circ} \mathrm{C}$. The serum obtained was stored at $-20^{\circ} \mathrm{C}$ until required for analysis.

\section{Seminal Analysis Using Computer Aided System (CASA)}

The cauda epididymis from each side of the testes was dissected out and several small cuts of about $1 \mathrm{~mm}$ made and the tissue suspended in $1 \mathrm{~m}$ of buffered formal saline to allow the spermatozoa to swim up. The assessment of sperm motility was done using Computer-Assisted Semen Analysis (CASA) in accordance with the method described by Breanna Tilley and WHO criteria $[27,28]$. The following measurements were obtained from the Total cell detected and was used for the computation of other patterns of motility, these included Total cell in sample $(106 / \mathrm{ml})$, Concentration $(106 / \mathrm{ml})$. Motile sperm, Motile sperm rate \%, Concentration of motile sperm (106/ml), Amplitude of Lateral Hunting (ALH) $\mu$, Wobbling (WOB) rate \%, Beating Cilia Frequency (BCF) in $\mathrm{Hz}$, Linearity (LIN) in \%, Straight forward line (SFR) \%, Progressivity (PR), Non-progressive, Immotility (IM), Velocity of Active Path (VAP) $\mu \mathrm{m} / \mathrm{s}$, Velocity of Curve Line (VCL) in $\mu \mathrm{m} / \mathrm{s}$, Velocity of Straight Line (VSL) in $\mu \mathrm{m} / \mathrm{s}$, Sperm of Curve moving, Sperm of Line moving, Sperm of Line moving fast, Concentration of curve moving (x106/ml), Concentration of line moving $(106 / \mathrm{ml})$, Concentration of line moving fast $(106 / \mathrm{ml})$, Percentage of curve movement (\%), Percentage of curve movement (\%), Percentage of line moving (\%), Percentage of line fast (\%), Rate of line moving (\%), Rate of line moving fast (\%) Morphology count: Normal Cell, Normality Rate (\%), Anomality Rate (\%), Defects, Anomality of Head, Head Anomality Rate (\%), Anomality of Body, Body Anomality Rate (\%), Anomality of Tail, Tail Anomality Rate (\%), Mixed Anomality, Mixed Anomality Rate (\%), Red Blood Cell (RBC), White Blood Cell (WBC), Epithelium, Spermatocyte.

\section{Rat Immunoglobulins Elisa Assay}

The Sandwich-ELISA method was employed for the determination of the immunoglobulins.

\section{Statistical Analysis}

Data were expressed as the mean + standard error of the mean. Data were analyzed using one-way analysis of variance (ANOVA), results obtained were further subjected to test for Least Significant Difference (LSD). Values of $\mathrm{P}<0.05$ were considered significant.

Results

\section{Sperm Concentration Following Treatment with Ethanol Leave Extract of Ageratum conyzoides and Nigerian Bonnylight Crude Oil}

The results obtained following the administration of Nigerian Bonny Light Crude Oil (NBLCO) and or leaf extracts of Ageratum conyzoides are presented in (Table 1). The results as presented in (Table 1) showed that administration of ethanol leaf extracts of Ageratum conyzoides significantly increase the percentages of total sperm cell detected (TSCD) and normal sperm cell (NSC) compared to the control group $(\mathrm{p}<0.05)$ but did not alter TSCC significantly. Administration of NBLCO to group III rats significantly lowered 
the percentages of TSCD, TSCC and NSC compared to the control and extract treated groups $(\mathrm{p}<0.05)$. The co-administration of Ageratum conyzoides with NBLCO significantly reduce TSCD, TSCC and NSC compared to the control and extract treated groups but significantly increased their values compared to the NBLCO treated group III, $(\mathrm{p}<0.05)$.

Table 1: The spermatozoa concentration following treatment with ethanol leave extract of Ageratum conyzoides and Nigerian Bonnylight crude oil.

\begin{tabular}{|c|c|c|c|}
\hline Groups & TSCD(10 $\mathbf{6} / \mathbf{m l})$ & TSCC (10 $\left.{ }^{\mathbf{6}} / \mathbf{m l}\right)$ & NSC $\mathbf{( \% )}$ \\
\hline I $(3 \mathrm{ml} / \mathrm{kg})$ & $81.60 \pm 0.68$ & $79.60 \pm 0.45$ & $69.80 \pm 0.49$ \\
\hline II $(748.33 \mathrm{mg} / \mathrm{kg})$ & $85.00 \pm 0.55^{\mathrm{a}}$ & $77.60 \pm 0.71$ & $83.00 \pm 0.84^{\mathrm{a}}$ \\
\hline III $(3 \mathrm{ml} / \mathrm{kg}$ of NBLCO) & $47.00 \pm 0.71^{\mathrm{a}, \mathrm{b}}$ & $34.60 \pm 0.75^{\mathrm{a}, \mathrm{b}}$ & $40.40 \pm 0.40 \mathrm{a}, \mathrm{b}$ \\
\hline IV $(3 \mathrm{ml} / \mathrm{kg}$ of NBLCO plus $748.33 \mathrm{mg} / \mathrm{kg})$ & $68.00 \pm 0.89^{\mathrm{a}, \mathrm{b}, \mathrm{c}}$ & $69.60 \pm 0.40^{\mathrm{a}, \mathrm{b}, \mathrm{c}}$ & $57.20 \pm 0.66^{\mathrm{a}, \mathrm{b}, \mathrm{c}}$ \\
\hline
\end{tabular}

Legend: TSCD = total sperm cell detected, TSCC $=$ total sperm cell concentrated, NSC = normal sperm cells. a, b, and d = significantly different from groups I, II, and III respectively $(\mathrm{p}<0.05)$.

Sperm Morphology Following Treatment with Ethanol Leave Extract of Ageratum conyzoides And Nigerian Bonnylight Crude Oil.

The results obtained following the administration of Nigerian Bonny light crude oil (NBLCO) and or leaf extracts of Ageratum conyzoides are presented in (Table 2). The results as presented in Table 2)showed that the ethanol leaf extract of Ageratum conyzoides did not alter Normality Rate (NR) significantly, but increase the percentage of Normal Sperm Cells (NSC) and significantly reduced Head Abnormality Rate (HAR), Body Abnormality Rate (BAR) and Total Abnormality Rate (TAR) significantly compared to the control group $(\mathrm{p}<0.05)$. The administration of NBLCO to group III rats significantly lowered the percentage of NSC and NR while it significantly increased HAR, BAR and TAR compared to control and extract treatd groups, $(\mathrm{p}<0.05)$. The co-administration of Ageratum conyzoides with NBLCO significantly reduced NSC and NR but significantly elevated HAR, BAR and TAR compared to the control and extract treated groups. The co-administration significantly elevated NSC and NR while significantly reduced HAR, BAR and TAR values compared to the NBLCO treated group III, $(\mathrm{p}<0.05)$.

Table 2: Comparing the spermatozoa morphology between the control, low, medium and high doses of ethanol leave extract of Ageratum conyzoides and Nigerian Bonnylight crude oil.

\begin{tabular}{|c|c|c|c|c|c|}
\hline Groups & NSC (\%) & NR (\%) & HAR (\%) & BAR (\%) & TAR (\%) \\
\hline I (Control) & $69.80 \pm 0.49$ & $78.40 \pm 0.40$ & $5.40 \pm 0.24$ & $6.40 \pm 0.24$ & $11.80 \pm 0.20$ \\
\hline II 748.33mg/kg of extract) & $83.00 \pm 0.84^{\mathrm{a}}$ & $78.20 \pm 1.02$ & $3.00 \pm 0.32^{\mathrm{a}}$ & $3.00 \pm 0.32^{\mathrm{a}}$ & $6.00 \pm 0.32^{\mathrm{a}}$ \\
\hline III(3ml/kg of NBLCO) & $40.40 \pm 0.40^{\mathrm{a}, \mathrm{b}}$ & $39.40 \pm 0.51^{\mathrm{a}, \mathrm{b}}$ & $33.20 \pm 0.92^{\mathrm{a}, \mathrm{b}}$ & $34.00 \pm 0.77^{\mathrm{a}, \mathrm{b}}$ & $67.20 \pm 0.73^{\mathrm{a}, \mathrm{b}}$ \\
\hline $\begin{array}{c}\text { IV (3ml/kg of NBLCO plus 748.33mg/ } \\
\text { kg ) }\end{array}$ & $57.20 \pm 0.66^{\mathrm{a}, \mathrm{b}, \mathrm{c}}$ & $63.20 \pm 0.97^{\mathrm{a}, \mathrm{b}, \mathrm{c}}$ & $16.00 \pm 0.55^{\mathrm{a}, \mathrm{b}, \mathrm{c}}$ & $12.40 \pm 0.68^{\mathrm{a}, \mathrm{b}, \mathrm{c}}$ & $28.00 \pm 0.55^{\mathrm{a}, \mathrm{a}, \mathrm{c}}$ \\
\hline
\end{tabular}

Legend: $a, b$, and $d=$ significantly different from groups I, II, and III respectively $(\mathrm{p}<0.05)$ NSC $=$ normal sperm cell, NR = normality rate, $\mathrm{HAR}=$ head anomality rate, $\mathrm{BAR}=$ body anomality rate, $\mathrm{TAR}=$ total anomality rate.

Spermatozoa Motility Following Treatment with Ethanol Leave Extract of Ageratum conyzoides and Nigerian Bonnylight Crude Oil

The results obtained following the administration of Nigerian Bonny light crude oil (NBLCO) and or leaf extracts of Ageratum conyzoides are presented in Table 3. The results showed that ethanol leaf extracts of Ageratum conyzoides significantly increase the percentage of motile sperm (MS) and progressivity with respect to the control group $(\mathrm{p}<0.05)$ and administration of NBLCO to group III rats significantly lowered the percentage of MS and progressivity than the control and A. conyzoides treated groups ( $p<0.05)$. The extract significant significantly lowered the percentages of immotile and non-progressive sperm compared with control $(\mathrm{p}<0.05)$.
NBLCO significantly elevated immotile and non-progressive sperm higher than control and extract treated groups $(\mathrm{p}<0.05)$. The results also showed that the co-administration of the extract significantly increased sperm motility and progressivity while significantly reducing the percentages of immotile and non-progressive sperm with respect to the NBLCO treated group III animals, $(p<0.05)$. Correlation results showing the relationship between sperm motility and seminal Antisperm Antibodies (ASA). The results as illustrated in (Figures 1-6), the correlation coefficients calculated between seminal antisperm antibodies (ASA) showed that seminal ASA significantly correlated negatively with Total Sperm Cell Concentration (TCC), Total Motile Sperm (TMS), Percentage Of Motile Sperm (PMS), and progressivity of sperm (PR), $(\mathrm{p}<0.05)$ but positively correlated with non-progressivity $(\mathrm{p}<0.05)$. 
Table 3: Spermatozoa motility for the control, extracts of A. conyzoides and NBLCO.

\begin{tabular}{|c|c|c|c|c|}
\hline Parameters & Group I & Group II & Group III & Group IV \\
\hline Motile Sperm (\%) & $74.00 \pm 0.45$ & $78.00 \pm 0.32^{\mathrm{a}}$ & $68.00 \pm 0.63^{\mathrm{a}, \mathrm{b}}$ & $62.40 \pm 0.68^{\mathrm{a}, \mathrm{b}, \mathrm{c}}$ \\
\hline Immotile Sperm (\%) & $5.80 \pm 0.58$ & $4.20 \pm 0.20^{\mathrm{a}}$ & $9.00 \pm 0.45^{\mathrm{a}, \mathrm{b}}$ & $22.40 \pm 0.60^{\mathrm{a}, \mathrm{b}, \mathrm{c}}$ \\
\hline Progressivity $(\mu \mathrm{m} / \mathrm{s})$ & $72.00 \pm 0.71$ & $79.00 \pm 0.32^{\mathrm{a}}$ & $76.60 \pm 0.68^{\mathrm{a}}$ & $59.00 \pm 0.63^{\mathrm{a}, \mathrm{b}, \mathrm{c}}$ \\
\hline Non-progressivity $(\mu \mathrm{m} / \mathrm{s})$ & $16.20 \pm 0.37$ & $9.60 \pm 0.60^{\mathrm{a}}$ & $8.40 \pm 0.24^{\mathrm{a}, \mathrm{b}}$ & $20.00 \pm 0.32^{\mathrm{a}, \mathrm{b}, \mathrm{c}}$ \\
\hline Linearity (\%) & $69.80 \pm 0.49$ & $83.00 \pm 0.84^{\mathrm{a}}$ & $81.60 \pm 0.75^{\mathrm{a}, \mathrm{b}}$ & $52.80 \pm 0.37^{\mathrm{a}, \mathrm{b}, \mathrm{c}}$ \\
\hline
\end{tabular}

Legend: $a, b, c$ and $d=$ significantly different from groups I, II and III $(\mathrm{p}<0.05)$.

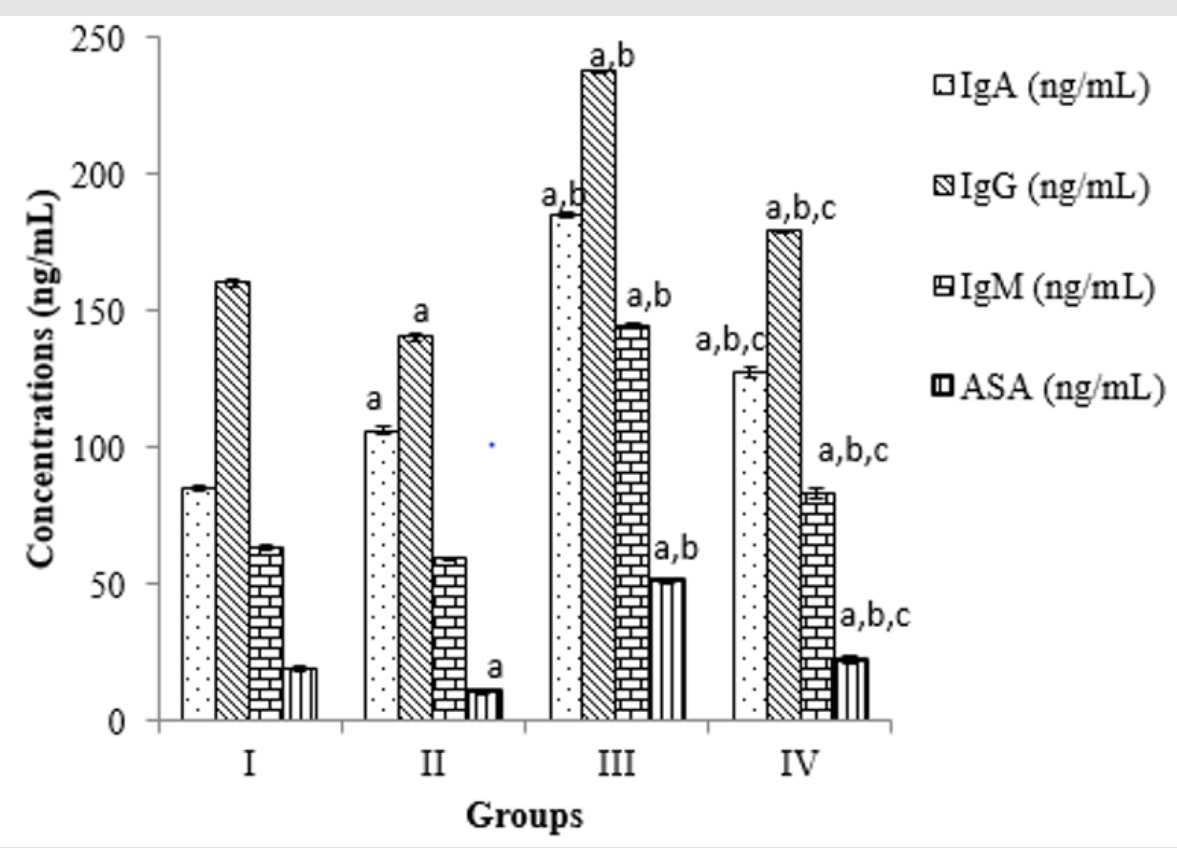

Figure 1: Comparing immunoglobulins and antisperm antibody concentration in NBLCO and extract of Ageratum conyzoides. $\mathrm{a}=$ versus group $\mathrm{I}, \mathrm{b}=$ versus group II and $\mathrm{c}=$ versus group III at $\mathrm{p}<$

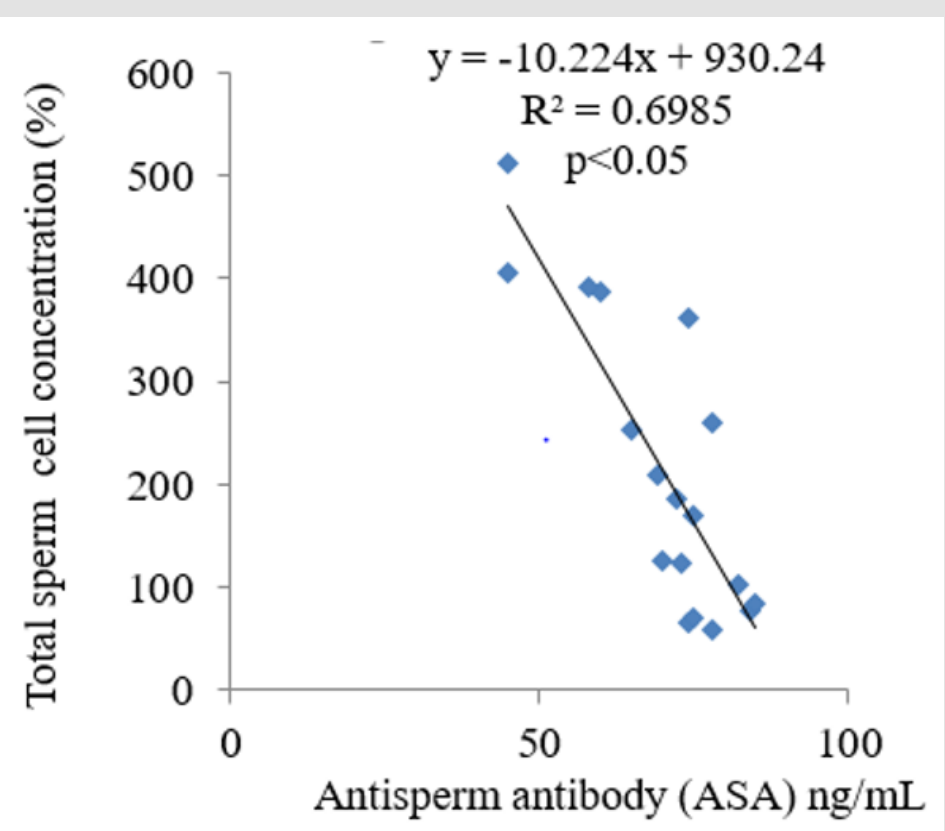

Figure 2: Relationship between total sperm cell concentration and ASA. 


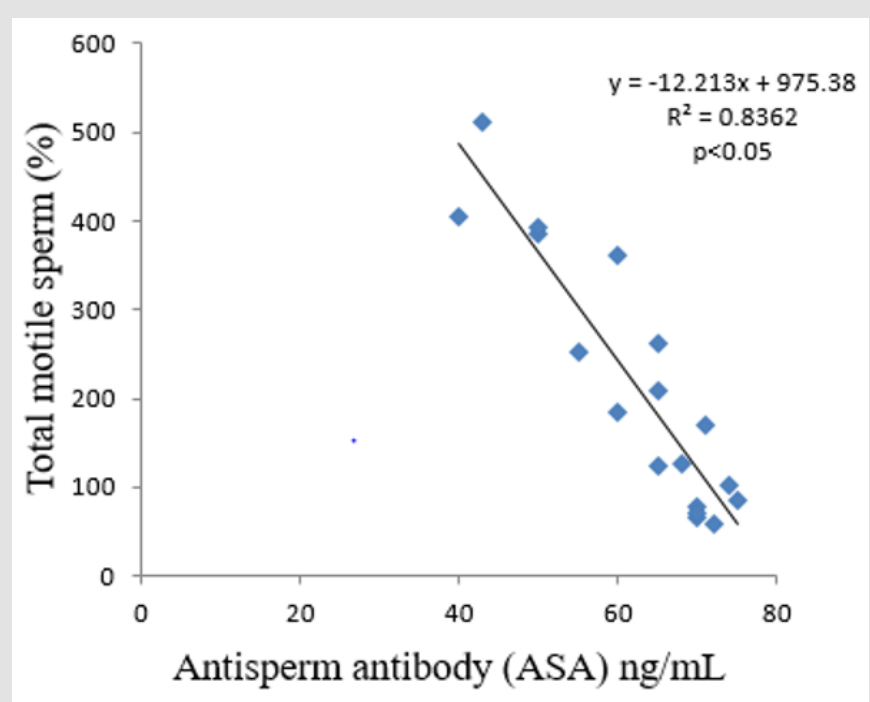

Figure 3: Relationship between total motile sperm and ASA.

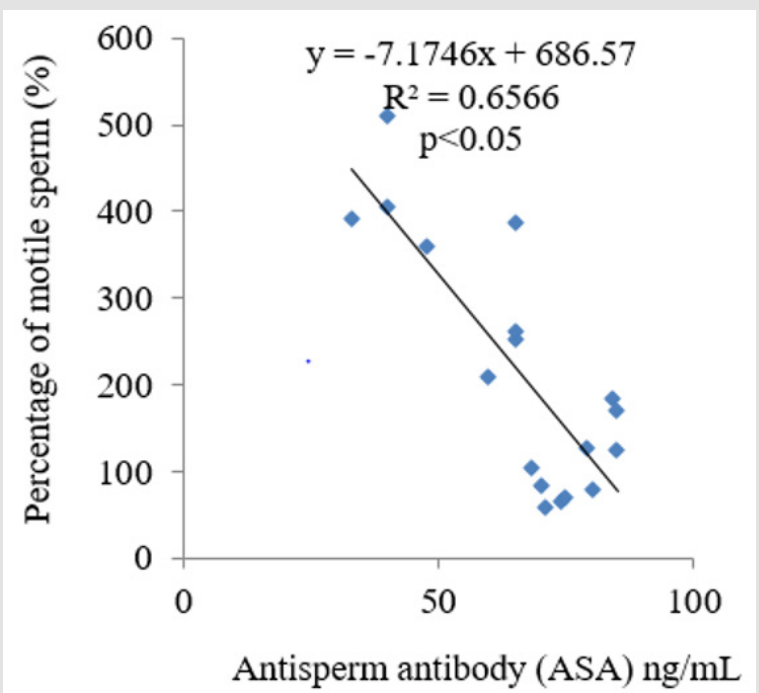

Figure 4: Relationship between percentage of motile sperm and ASA.

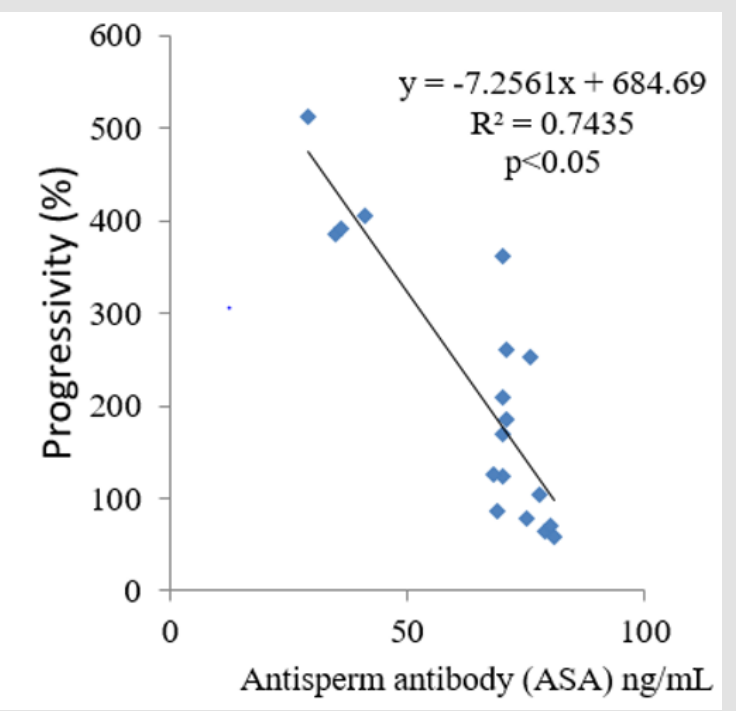

Figure 5: Relationship between sperm progressivity and ASA. 


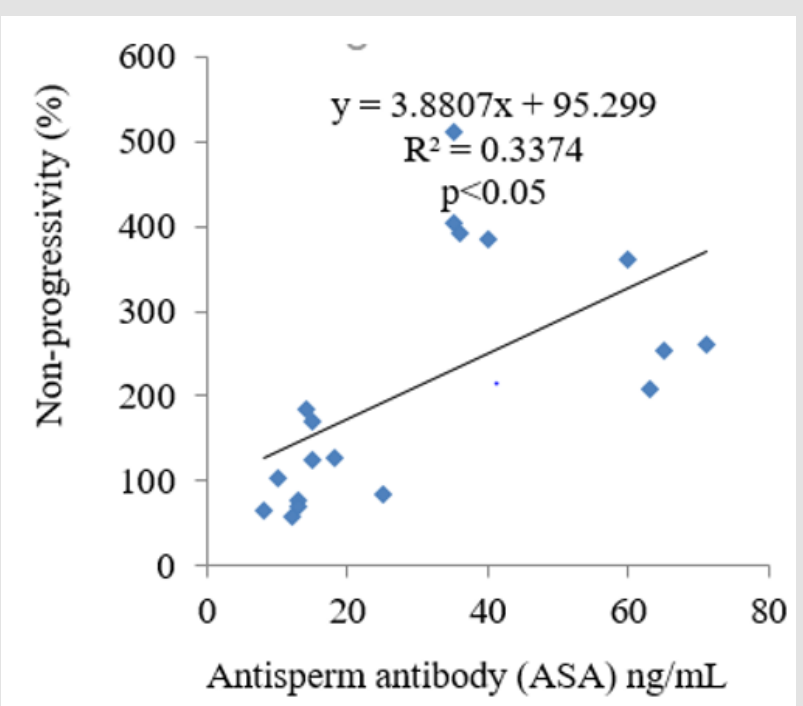

Figure 6: Relationship between sperm non-progressivity and ASA.

\section{Discussion}

The interference of oral administration of NBLCO with normal sperm functions by interfering with sperm concentration, motility and morphology has been demonstrated in this study. The administration of NBLCO to male rats significantly reduced total sperm cells detected (TSCD), total sperm cell concentration (TSCC) and normal sperm cell (NSC). It was also observed that the morphology of the sperm cells was not spared as indices for assessing sperm morphology, such as Head Abnormality Rate (HAR), Body Abnormality Rate (BAR) and Total Abnormality Rate (TAR) were significantly increased. With respect to sperm motility, NBLCO significantly reduce motility indices such as the percentage of motile sperm (MS) and progressivity while increasing percentages of immotile and non-progressive sperm. These findings suggest that NBLCO is injurious to sperm cells and might impact fertility capacity negatively. The negative impact of NBLCO on sperm concentration, morphology and motility is in consonance with similar reports in literature where crude oil was reported to have impacted negatively on sperm cell efficiency, as was illustrated by the significant reduction in the percentage of motile sperm as well as increasing abnormal morphology of sperm cells [29].

Interference with normal spermatozoa motility and morphology such as the type demonstrated in this study can influence their viability and efficiency, so proper evaluation of sperm concentration, motility, and morphology remain veritable properties required for effective and efficient sperm functions. Apart from the fact that spermatozoa must be produced in sufficient numbers, exhibition of normal motility and shape is essential to overcome passage resistance offered by the highly viscous cervical mucus and uterus, to reach the ampullae of the oviducts of the female organism for fertilization. Abnormal sperm motility and morphology could prevent the sperm's contact with an ovum to prevent fertilization as incapacitation of the contractile proteins impacts on motility coupled with altered morphology have been reported to have impacted on the viability of sperm and could perhaps result in male infertility $[10,11]$. Crude oil contains harmful compounds such as polycylic aromatic hydrocarbons that could cause variation in sperm quality and function, particularly, affecting the contractile elements of the sperm cell.

Therefore, interference with normal sperm concentration and morphology could probably lead to male infertility; by increasing the number of morphologically abnormal sperms as reported in this study, this could result in impaired sperm motility. It is for this reason that Gandini and colleagues postulated that sperm function dependent much on sperm morphology and should be seen as the primary predictor of fertility potential in male [30]. The administration of NBLCO was also demonstrated in this study to significantly increase the immunoglobulins (IgA, IgG and IgM) levels as well as the antisperm antibodies. Since the NBLCO is reported to exert its hazardous effect through induction of oxidative stress and lipid peroxidation, this could probably explain its ability to cause infertility. Oxidative stress laced up with inflammation process in the seminal fluid can evoke immune response with the attended consequences of formation of antisperm antibodies (ASAs) as reported in this study.

The NBLCO administration in this study probably may have evokes ASAs production exponentially to instigate seminal agglutination to impede sperm movements. This was however reversed with co-administration of antioxidant-rich ethanol leaves extract of Ageratum conyzoides. ASAs can be detrimental to sperm's heath where they exhibit cytotoxic tendency on the spermatozoa and could cause immobilization of sperm cells and even sperm death. High levels of ASAs can also instigate high coagulability tendencies in the semen to increase agglutination of moving sperm in semen by forming clumps to immobilize the sperm, this action in turn impede free passage of sperm through the mucus-rich but 
highly viscous cervical wall and uterus to the fallopian tube to interact with the ovum, thereby reducing fertilization capacity of the sperm cell [18].

The correlation analysis between Total Motile Sperm (TMS), Percentage Of Motile Sperm (PMS), Progressivity (PR), Total Sperm Cell Concentration (TCC) and Non-Progressivity (NP) Against Antisperm Antibody (ASA) respectively showed that TMS, PMS, PR and TCC correlated negatively with ASA while sperm non-progressivity correlated positively with ASA. These findings again confirm the likely impairment of sperm motility due to high concentration of ASA; this may probably contribute to the process of infertility in male. In contrast, independent administration of Ageratum conyzoides significantly increase sperm quality and relative function by increasing sperm concentration, maintenance of normal sperm morphology, increase parameters that encourages sperm motility and reducing the percentage of immotile sperm and sperm progressivity. The co-administration of extract of Ageratum conyzoides with NBLCO has also demonstrated significant reversibility of the negative impacts of the crude oil on the aforementioned parameters.

It has been proposed that NBLCO is injurious to many body cells and tissues, the injuries or damages to cellular elements probably occurred through generation of radical oxidants and lipid peroxidation. The body is therefore equipped with spectrum of natural antioxidant systems to protect against these oxidative damages and also repairs damaged molecules [31]. In spite of these protective mechanisms, exposure to NBLCO has been reported to spike up and amplified oxidative damages such that the natural antioxidant mechanism is insufficient to mop up the oxidant radicals generated [32]. In this study, excessive production of free radicals occasioned by the administration of NBLCO without corresponding antioxidant systems can be detrimental to sperm by destroying the contractile proteins and lipid components of the sperm membrane and this may lead to male infertility as sperm plasma membrane is particularly susceptible to peroxidation because of its high content of unsaturated fatty acids $[12,13]$.

The aforementioned events could destroy the structure of the sperm membrane lipid matrix [14], accompanied with destructions of contractile protein elements in sperm tail resulting in defective membrane integrity and loss of motility. The ease with which spermatozoa pass through cervical mucus is highly dependent on their rapid progressive motility $[15,16]$, which in turn is dependent on the integrity of the contractile components of the sperm membrane, particularly the tail. For the reason (s), the experimental animals were supplemented with ethanol leaves extract of Ageratum conyzoides with a view to ameliorates and prevent these effects. The plant, Ageratum conyzoides could probably have offered protection against hazardous effects of NBLCO because of its extensive antioxidant reservoir [33].

\section{Conclusion}

The Nigerian Bonnylight Crude Oil has been shown to be spermatotoxic by significantly reducing sperm motility and normal sperm morphology. The NBLCO exert its hazardous effects through induction of oxidative stress and lipid peroxidation, the process that could induce inflammation process in the seminal fluid to evoke immune response with the attended consequences of formation of Antisperm Antibodies (ASAs) as reported in this study. The significantly higher ASAs levels can be detrimental to sperm's heath where they exhibit cytotoxic tendency on the spermatozoa and could cause immobilization of sperm cells by induction of seminal agglutination of moving sperm cells and even sperm death. It is possible to postulate that supplementation with Ageratum conyzoides could increase sperm cell resistance to crude oil toxicity including preventing the coagulability process, and thereby improving viability of sperm cells to improve fertility capacity. Such supplementation will be of great advantage to animals and humans who are exposed to crude oil. It is therefore concluded that NBLCO is spermatotoxic, which could be ameliorated with administration of Ageratum conyzoides.

\section{References}

1. Lyons RA, Temple JM, Fone DL (1999) Acute health effects of the sea oil spill. Journal of Epidemiology and Community Health 53(5): 306-310.

2. Izegbu MC, Ojo MO, Shittu LAJ (2005) Clinical pathological pattern of testicular malignancies in Ilorin, Nigeria-a report of 8 cases. Journal of Cancer research and therapeutics 1(4): 229-231.

3. Shittu LAJ, Bankole MA, Oguntola JA, Ajala O, Shittu RK, et al. (2007) Sesame Leaves Intake Improve and Increase Epididymal Spermatocytes Reserve in Adult Male Sprague Dawley Rat. Scientific Research and Essays 2(8): 319-324.

4. Shittu LAJ, Shittu RK, Ajala MO, Bankole MA, Benebo AS, et al. (2008) Sesame radiatumphytoestrogenic ligand enhances testicular activity in Adult Male Sprague Dawley Rat Testis. International Journal of Morphology 26(3): 643-652.

5. Orisakwe OE, Akumka DD, Njan AA, Afonne OJ (2004) Testicular toxicity of Nigerian Bonny light crude oil in male albino rats. Reproductive Toxicology 18(3): 439-442.

6. Adesanya OA, Shittu LAJ, Omonigbehin EA, Tayo AO (2009) Spermatotoxic impact of Bonny light crude oil (BLCO) ingestion on adult male Swiss albino mice. International Journal of Physical Sciences 4(5): 349-353.

7. Farombi EO, Adedara IA, Ebokaiwe AP, Teberen R, Ehwerhemuepha T (2010) Nigerian Bonny Light Crude Oil Disrupts Antioxidant Systems in Testes and Sperm of Rats. Journal of Archives of Environmental Contamination and Toxicology 59: 166-174.

8. Bonde JP (1996) Environmental Factors. In: Comhaire, FH (ed.), Male Infertility, Clinical Investigation, Cause Evaluation and Treatment. Chapman and Hall, London pp. 267-284.

9. Spira A, Multigner L (1998) The effect of industrial and agricultural pollution on human spermatogenesis. Human Reproduction 13(8): 2041-2042.

10. Eliasson R (2010) Semen analysis with regard to sperm number, sperm morphology and functional aspects. Asian J Androl 12(1): 26-32.

11. Lamb DJ (2010) Semen analysis in 21st century medicine: the need for sperm function testing. Asian J Androl 12(1): 64-70. 
12. Aitken RJ (1998) The role of free oxygen radicals and sperm function. International Journal of Andrology 12(2): 95-97.

13. Agarwal A, Makker K, Sharma R (2008) Clinical relevance of oxidative stress in male factor infertility: an update. American Journal of Reproductive Immunology 59(1): 2-11.

14. Sönmez M, Turk G, Yuce A (2005) The effect of ascorbic acid supplementation on sperm quality, lipid peroxidation and testosterone levels of male Wistar rats. Theriogenology 63: 2063-2072.

15. Lindholmer C (1974) The importance of seminal plasma for human sperm motility. Biol Reprod 10(5): 533-542.

16. Björndahl L (2010) The usefulness and significance of assessing rapidly progressive spermatozoa. Asian J Androl 12(1): 33-35.

17. Aitken RJ, Sutton M, Warner P, Richardson DW (1985) Relationship between the movement characteristics of human spermatozoa and their ability to penetrate cervical mucus and zona-free hamster oocytes. J Reprod Fertil 73(2): 441-449.

18. Mortimer D (1994) Practical Laboratory Andrology. Oxford University Press, New York, USA, pp. 66-69.

19. Larson RA (1988) The antioxidants of higher plants. Phytochemistry 27: 969-978.

20. Misra LN, Kumar S (1997) Indian medicinal plants as a potential source of therapeutic agents. In: Harvesting Herbs-2000. Nautiyal, AR (Eds.) Bishen Singh Mahendra Pal Singh Press, Dehrandum, India, p. 13-27.

21. Velioglu YS, Mazza G, Gao L, Oomah BD (1998) Antioxidant activity and total phenolics in selected fruits, vegetables and grain products. Journal of Agriculture and Food Chemical 46(10): 4113-4117.

22. Kahkonen MP, Hopia AI, Vuorela HJ, Rauha J, Pihlaja K, et al. 1999) Antioxidant activity of plant extracts containing phenolic compounds. Journal of Agriculture and Food Chemical 47(10): 3954-3962.

23. Misra LN, Siddiqui MS, Singh AK, Shukla YN (2000) Essential oils of cymbopogons: chemistry, uses and biological activities. In: Aromatic grasses. Kumar.

ISSN: 2574-1241

DOI: $10.26717 /$ BJSTR.2020.29.004751

Sunday Otu Ita. Biomed J Sci \& Tech Res

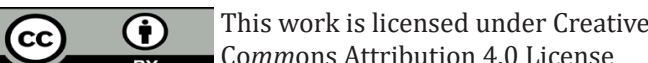

Submission Link: https://biomedres.us/submit-manuscript.php
24. Dragland S, Senoo H, Wake K, Holte K, Blomhoff R (2003) Several culinary and medicinal herbs are important sources of dietary antioxidants. Journal of Nutrition 133(51): 1286-1290.

25. Tuli R, Sangwan RS, Kumar S, Bhattacharya S, Misra LN (2009) Ashwagungha (Withaniasomnifera): A model Indian medicinal plant. CSIR, New Delhi, India.

26. Lorke D (1993) A new approach to Practical Acute Toxicity Testing. Archieve of Toxicology 54(4): 275-287.

27. Breanna Tilley BS (2007) Assessment of Boar Sperm Samples by Computer-Assisted Sperm Analysis and the Mobility Assay. Texas Tech University.

28. (1999) World Health Organisation Laboratory manual for the examination of human semen-cervical mucus interaction. $4^{\text {th }}$ edn. Cambridge: Cambridge University Press pp. 1-86.

29. Fischer VA, Fischer CE, Akpaso M, Igbigbi PS (2016) Effects of Ingestion of Bonny Light Crude Oil on Sperm Motility and Morphology of Male Wistar Rats. International Journal of Science and Research 5(10): 12301233.

30. Gandini L, Lombardo F, Paoli D, Caponecchia L, Familiari G, et al. (2000) Study of apoptotic DNA fragmentation in human spermatozoa. Human Reproduction 15: 830-839.

31. Marian V, Dieter L, Jan M, Mark TDC, Milan M, et al. (2007) Free radicals and antioxidants in normal physiological functions and human disease. The International Journal of Biochemistry and Cell Biology 39(1): 44-84.

32. Ita SO, Effiong EF, Okon MS, Robert AS, Francis UE (2018) Impact of Crude Oil-induced Oxidative Stress and Lipid Peroxidation on Spermatogenesis: The Anti-Oxidative Role of Ageratum conyzoides. J Reproductive Endocrinol \& Infert 3(1): 26.

33. Tandon SK, Chandra S, Tripathi HC (1994) Pharmacological effects of Ageratum conyzoides roots. Indian Journal of Pharmaceutical Sciences 56: $182-185$.

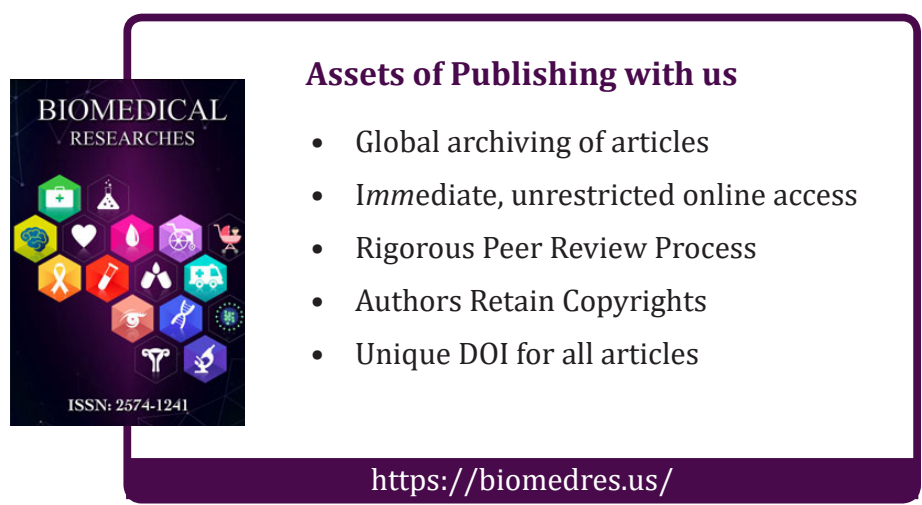

